DOI https://doi.org/10.36059/978-966-397-190-2/1-16

\title{
CONSTITUALITY OF CONSTITUTIONAL REFORM: SOME ISSUES OF CONFORMITY TO THE IDEAS OF CONSTITUTIONALISM
}

\section{Olena Boryslavska}

\section{INTRODUCTION}

The recent history of many Eastern European countries reveals the events that qualify as constitutional reforms. After leaving the socialist camp and starting to move toward constitutional systems based on the ideas of constitutionalism, these countries adopted new democratic constitutions (Poland 1997, Romania 1991, Slovakia 1992, Moldova 1994, Ukraine 1996) or reinstated the constitutions of the beginning of the twentieth century (Latvia 1993, Lithuania 1990). However, not a decade has passed since then, when many of them were subject to constitutional amendments (or new Constitutions were adopted, as in Hungary in 2011). Moreover, some of them significantly changed the constitutional reality.

On the one hand, this seems to be a logical process of the constitutional development of the state, which, having introduced new institutions and mechanisms for itself, refines them after some time, using the accumulated experience. However, on the other hand, an analysis of the content of such constitutional changes, as well as of the political conditions and procedures used to implement them, causes serious reflections about the possible decline of constitutionalism as well as serious problems with its functioning.

The question arises as to the constitutionality of such reforms. Under constitutionality in this case, we mean the principles of constitutionalism, which are crucial for the existence of a constitutional state: respect for human rights, separation of powers, independence of court, and rule of law rather than the formal compliance with the rules and procedures for amending the constitution.

For example, in Hungary, after the formation of the parliamentary coalition around the Fidesz party following the 2010 elections results, the process of renewing the constitutional regulation began almost immediately. Moreover, within a few months, the ruling coalition amended the constitution 10 times $^{1}$; some of the amendments were extremely controversial. At the same

\footnotetext{
${ }^{1}$ Venice Commission Opinion on three legal questions arising in the process of drafting the new Constitution of Hungary, Strasbourg, 28 March 2011, p. 8, URL: http://www.venice.coe.int/ webforms/documents/default.aspx?pdffile $=$ CDL-AD(2011)001-e
} 
time, it was decided to adopt a new Constitution, which had to completely replace the previous one. The drafting of the new Constitution in 2011 was handled by the Ad-hoc Parliamentary Constitutional Committee. The ruling party actively participated in it, while opposition members boycotted the committee's work in protest against the restriction of the powers of the Constitutional Court as a result of the 2010 constitutional amendment. Drafted by the Parliamentary Constitutional Committee, the act amending the constitution was submitted to the Parliament in March 2011, in April adopted and signed by the President ${ }^{2}$.

Such a speed and at the same time a closed procedure of preparation and adoption of the new Constitution made its discussion by political forces, mass media and civil society less possible, which was severely criticized both within the country and by the European institutions ${ }^{3}$. At the same time, the content of a number of provisions of the 2012 Constitution in their complex testifies to the desire of the parliamentary majority, the party around which it is formed, and its leader to get rid of serious constitutional restrictions and to concentrate power.

Another example is the Romanian Constitution adopted in 1991, which consolidated liberal-democratic values at the national level and created the preconditions for the formation of a constitutional government. However, in 2009, an unsuccessful attempt was made to reform the system of separation of powers (earlier, in 2003, the Constitution was amended due to EU membership); this attempt was repeated in 2013. All this took place amid constant political conflicts, pressure on the Constitutional Court and attempts to concentrate power.

An interesting example of "unconstitutional constitutional reform" is the attempt to reform the judiciary in Poland. Another interesting fact is that this reform does occur without interfering with the text of the Constitution, but it attacks basic constitutional values and principles (which gives grounds to consider it unconstitutional). The crisis related to attempts to depend on the judiciary has been ongoing in Poland since 2015, when the "Right and Justice" political party simultaneously gained a majority in the Senate and the Seimas, formed a government and won the presidential election. Only the Constitutional Tribunal and the judiciary prevented the final concentration of power, and politicians urgently called for "reform". Without going into the details of the Polish crisis, it should be noted that it has been continuing till

\footnotetext{
${ }^{2}$ Venice Commission Opinion on the New Constitution of Hungary, Strasbourg, 20 June 2011. URL: http://www.venice.coe.int/webforms/documents/default.aspx?pdffile=CDL-AD(2011)016-e

${ }^{3}$ Venice Commission Opinion on three legal questions arising in the process of drafting the new Constitution of Hungary, Strasbourg, 28 March 2011. URL: http://www.venice.coe.int/ webforms/documents/default.aspx?pdffile=CDL-AD(2011)001-e
} 
nowadays; and the aforementioned events have received a clear assessment by the European bodies and institutions as an attack on constitutional democracy ${ }^{4}$.

As we can see, in all these cases the constitutional amendments were either aimed at concentration of power or contradicted the original ideas of constitutionalism. And this, even in compliance with formal requirements, testifies to the phenomena that contradict the essence of the constitutional state (a state with constitutionally restricted power, whose main task is to guarantee human rights and fundamental freedoms).

That is why it seems necessary to discuss an issue of the constitutionality of constitutional reform - its conformity not only and not so much with the "letter of the constitution" as with the spirit of constitutional principles, the universal ideas of constitutionalism. In addition, an important but not the only indicator of the constitutionality of constitutional reform is adherence to the established procedure for amending the Constitution, since it ensures the exercise of constituent power, which is one of the basic principles of constitutionalism and the basis for the functioning of the constitutional state, respectively.

This small study aims to develop the concept of constitutional reform, its key parameters, elements and features that ensure its constitutionality as well as its efficiency.

First of all, we will focus on the essence of constitutional reform in order to differentiate it from other related phenomena, because not every constitutional change is a constitutional reform. And from a practical point of view, it is very important to understand the technology of conducting a constitutional reform. It is clear that its effectiveness depends not only on the legal component, but also on socio-political preconditions and circumstances. However, without good legal support, constitutional reform is unlikely to succeed.

Besides this, it is very important to provide constitutional reform in the spirit of the ideas of constitutionalism, which ensures the development of the state as constitutional but not aimed at limiting human rights, usurpation or

${ }^{4}$ European Parliament resolution of 13 April 2016 on the situation in Poland. URL: http://www.europarl.europa.eu/oeil/popups/ficheprocedure.do?lang=en\&reference=2015/3031(RS P); European Parliament resolution of 14 September 2016 on the recent developments in Poland and their impact on fundamental rights as laid down in the Charter of Fundamental Rights of the European Union. URL: http://www.europarl.europa.eu/sides/getDoc.do?type=TA\&reference=P8TA-2016-0344\&language=EN; European Parliament resolution of 15 November 2017 on the situation of the rule of law and democracy in Poland. URL: http://www.europarl.europa.eu/ sides/getDoc.do?type=TA\&language $=E N \&$ reference $=$ P8-TA-2017-0442; European Parliament resolution of 28 January 2020 on the Functioning of democratic institutions in Poland. URL: http://assembly.coe.int/nw/xml/XRef/Xref-DocDetails-EN.asp?FileID=28504\&lang=EN 
excessive concentration of power, violation of the judiciary independence or other important constitutional principles. Therefore, we will further analyze the elements and features of constitutional reform which testify to its constitutionality and effectiveness.

\section{Essense of the concept of "constitutional reform"}

Quite often, any change in the text of the constitution is understood as constitutional reform in the science. For example, Agafonova N.V. considers that the terms "constitutional amendment" and "revision of the constitution" (full or partial) are covered by the term of constitutional reform, and that constitutional reform can be considered as a generic concept of amending the constitution. Under constitutional reform, the scientist understands:

“... conditioned by the needs of society political and legal phenomenon related to the changes of the Basic Law, which are conducted on the basis of fundamental, value principles of the constitutional order, within the framework of the constitutional process and aimed at improving state organization and subordinate to the goals of social development ${ }^{5}$.

Based on the above definition, any interference with the text of the constitution will be considered as constitutional reform, even if does not alter the constitutional system, nor does it significantly affect the scope of guaranteed human rights. Contrary, as regards the amendments to the Constitution of the USA, James Sundquist divides them into essential for the constitutional system and peripheral (technical).

"Only five of the twenty-seven amendments dealt with the structure of government created by the Constitution, ... and of those five, three can be considered technical or peripheral; they corrected flaws in the design of the structure or adapted it to new circumstances without altering the nature or relationships of the institutions as the framers had conceived them. ... Even those two amendments influenced the institutions only indirectly".

As a result, he concludes that the country's state architecture has proved to be "amazingly durable" in a world change, which means essentially unchanged, not constitutionally reformed, except for the two mentioned times.

In our view, not every change to the constitution can and should be considered as constitutional reform. To be categorized as constitutional reforms, such changes must have certain characteristics.

${ }^{5}$ Ahafonova N.V. Konstytutsiina reforma v Ukraini: poniattia, instytutsiinyi mekhanizm ta zabezpechennia efektyvnosti. (Constitutional Reform in Ukraine: Concept, Institutional Mechanism and Effectiveness Support). Avtoreferat dysertatsii na zdobuttia naukovoho stupenia doktora yurydychnykh nauk. Kyiv, 2017 (in Ukrainian).

${ }^{6}$ Sundquist James. L. Constitutional reform and effective government. Washington D.C.: Brookings Institution, Revised edition, 1992. P. 4-5. 
First, they must relate to substantial issues of the constitutional order, human rights, constitutional system, separation of powers or organization of the state. Moreover, the question whether to interpret such issues as significant or not occurs in each case. Undoubtedly, examples of constitutional reform in Ukraine are the adoption of the Laws on Amendments to the Constitution of Ukraine on Justice ${ }^{7}$ or on the State's strategic course for the acquisition of full membership of Ukraine in the European Union and in the North Atlantic Treaty Organization ${ }^{8}$. Contrary, for example, the simultaneous extension of the term of office of the Verkhovna Rada and the elected local self-government bodies from 4 to 5 years within the framework of the existing system of organizing public authority did not significantly affect it, nor the status, powers or role of local self-government bodies, and therefore it was not a constitutional reform (though a solution to the issue was also outlined in the Constitution Amendment $\mathrm{Act}^{9}$ ).

It should be noted that the same textual changes can in one case significantly affect the constitutional system and in the other case be just technical. The last of abovementioned laws provided for the unification of the terms of office of the President, the Verkhovna Rada and the elected local self-government bodies without affecting the system of separation of state power or division of competencies between the state and local selfgovernment, while maintaining the balance existing at that time. However, in other political circumstances, the same change in the term of office of public authorities could have a significant impact on the political system, which should be carefully analyzed in each case of interference with the text of the constitution.

Second, adherence to the constitutional procedure for their approval is essential for qualifying amendments to the Constitution as "constitutional" constitutional reform. This is linked with the broader issue of the legitimacy of constitutional changes. Thus, of the six constitutional reforms that took place in Ukraine after the adoption of the 1996 Constitution, three were related to doubts about their legitimacy because of violations of the constitutional procedure.

${ }^{7}$ Pro vnesennia zmin do Konstytutsii Ukrainy (shchodo pravosuddia). Zakon Ukrainy vid 02.06.2016 № 1401-VIII. URL: https://zakon.rada.gov.ua/laws/show/1401-19 (in Ukrainian).

${ }^{8}$ Pro vnesennia zmin do Konstytutsii Ukrainy (shchodo stratehichnoho kursu derzhavy na nabuttia povnopravnoho chlenstva Ukrainy $v$ Yevropeiskomu Soiuzi ta $v$ Orhanizatsii Pivnichnoatlantychnoho dohovoru). Zakon Ukrainy vid 07.02.2019 № 2680-VIII. URL: https://zakon.rada.gov.ua/laws/show/2680-19 (in Ukrainian).

${ }^{9}$ Pro vnesennia zmin do Konstytutsii Ukrainy shchodo provedennia cherhovykh vyboriv narodnykh deputativ Ukrainy, Prezydenta Ukrainy, deputativ Verkhovnoi Rady Avtonomnoi Respubliky Krym, mistsevykh rad ta silskykh, selyshchnykh, miskykh holiv. Zakon Ukrainy vid 01.02.2011 № 2952-VI. URL: https://zakon.rada.gov.ua/laws/show/2952-17 (in Ukrainian). 
The first amendments to the Constitution of Ukraine were made in December 8, 2004 as a result of events that became known as the "Orange Revolution", when the society did not recognize the officially announced results of the presidential elections. Therefore, the two laws on Amendments to the Constitution and holding the third round of the presidential elections between two candidates who had received the greatest support from voters in the first round were simultaneously adopted by the so-called "package" voting. It should be noted that the adoption of the Law on Amendments to the Constitution was a gross violation of the procedures analyzed in detail in the opinion of the Venice Commission ${ }^{10}$. This became a formal ground for cancellation of the constitutional reform in 2010.

However, the submission to the Constitutional Court had been brought in before, but in 2008 the Court refused to hear the case, referring to the fact that the Law on Amendments to the Constitution after its entering into force becomes the integral part of the Constitution, and the Court does not have the authorities for the revision of the Constitution. After the presidential elections in 2010, the Constitutional Court changed its legal position and considered the Law on Amendments to the Constitution in 2004. He found it unconstitutional due to the violations of the aforementioned procedures and reinstated the Constitution of 1996. The body of constitutional jurisdiction actually had become the subject of constitutional reform, which was criticized by the Venice Commission.

Due to the events of late 2013 - early 2014, the Verkhovna Rada of Ukraine again recognized the Constitution as amended of 2004 in force, referring to the fact that the Constitution is an act of constituent power, the competence of its amending is vested only in the parliament (Section XIII of the Constitution), and the Constitutional Court which carried its decision in 2010 went beyond its powers. This was done not by the adoption of a constitutional law, as required by the section XIII of the Constitution, but by an ordinary law by simple majority of deputies. That is the reason why the legitimacy of the constitutional amendments is questionable until now.

In addition to the adherence to the constitutional procedure under the conditions of a constitutional state such features of constitutional reform that ensure the implementation of the ideas of constitutionalism guarantee the further development of the state as a constitutional one and not aimed at restricting human rights, usurpation or excessive concentration of power, violation of independence, are equally important to court or other important

${ }^{10}$ Venice Commission Opinion on the amendments to the Constitution of Ukraine adopted on 8.12.2004, adopted by the Commission at its 63rd plenary session, Venice, 10-11 June 2005. URL: https://www.venice.coe.int/webforms/documents/?pdf=CDL-AD(2005)015-e. 
issues for the functioning of the constitutional system of limited governance. In our view, such features include the legitimate aim and legitimacy of the reform itself.

Thus, mandatory features of constitutional reform (under the constitutional state) are: 1) the legitimate aim of constitutional reform, focused on achieving a legitimate result (improvement of the system of separation of powers, guarantees of human rights, organization of the state, etc.); 2) tangible, serious consequences for the constitutional system; 3) legitimacy of the reform adherence to the constitutional procedure for its implementation; 4) systemic character of the reform. An optional feature is the effectiveness of constitutional reform, which is assessed in each case by the ratio of the defined goal and the result achieved.

The above features of constitutional reform are logically related to its elements. As noted above, it is important for practice to find out a structure for constitutional reform that optimally meets the requirements of its effectiveness and constitutionality. In our opinion, based on the set parameters, the elements of constitutional reform are: 1) the purpose of reform (which must be legitimate); 2) reform strategy (should ensure the most optimal and organized way to achieve the purpose of reform; 3 ) the content of the reform (proposed changes); 4) the reform procedure (should ensure its legitimacy); 5) the mechanism of reform (covering the whole set of measures, both those envisaging amendments to the constitutional text and others necessary for implementation of the reform).

The logical link between the elements of constitutional reform and its features can be summarized in the form of a table:

\begin{tabular}{|c|c|c|}
\hline 1. & $\begin{array}{c}\text { Elements } \\
\text { of constitutional reform }\end{array}$ & $\begin{array}{c}\text { Features } \\
\text { of constitutional reform }\end{array}$ \\
\hline 2. & Purpose of reform & Legitimate purpose \\
\hline 3. & Content of the reform & $\begin{array}{l}\text { Significant consequences for the } \\
\text { constitutional system }\end{array}$ \\
\hline 4. & Reform strategy & Systemic character of the reform \\
\hline 5. & Reform procedure & Legitimacy \\
\hline 6. & Mechanism of reform & Efficiency \\
\hline
\end{tabular}

\section{Elements of the constitutional reform \\ 2.1. The purpose of the constitutional reform}

The first and basic element of constitutional reform is its purpose. It is quite clear that the goal defines all other elements of constitutional reform, preferably with the exception of the procedure, which is usually standard. However, there may be some peculiarities as well. For example, if the purpose 
of constitutional reform in Ukraine is related to the amendment of constitutional provisions on the principles of constitutional order, elections and referendums or the procedure for constitutional amendments (these issues are regulated by sections I, III and XIII of the Constitution), then the procedure will differ from the procedure for changing other sections of the Constitution of Ukraine (it is much more complex and, among other things, requires the approval of constitutional changes in a national referendum).

A wording of the objective is crucial to the success of the reform. First of all, we remind that we proceed from the provision of two key parameters of constitutional reform - its constitutionality and effectiveness. Based on these, the goal of constitutional reform should be defined as clearly and transparently as possible. First, it reaffirms the legitimacy of the goal and contributes to the legitimacy of the reform as a whole, as well as provides a basis for understanding its content; secondly, it facilitates the competent design of the reform strategy; thirdly, it allows selecting as adequately as possible the tools and the mechanism of the implementation of the constitutional reform.

An example of a poorly formulated goal, which subsequently led to negative consequences, is experience of the constitutional reforms initiated in Ukraine in 2019. While it is still too early to make a final decision whether these reforms are successful or unsuccessful, since most of them are still undergoing, it is already possible to predict the ineffectiveness, illegitimacy (in terms of support and public acceptance) of some of them.

Obviously, on August 29, 2019, on the second day of the Verkhovna Rada of Ukraine of the IX convocation, the President of Ukraine submitted seven bills on amendments to the Constitution, which were previously approved by the Verkhovna Rada of Ukraine. However, the purpose of the proposed amendments was not announced to the public by the subject of initiating constitutional reforms. In the explanatory notes to the bills, in which their purpose is to be reflected, it is either reflected in a little-verbatim (one sentence), without justification of its necessity, or is clearly stated in error.

For example, in the explanatory note to the Bill on the Abolition of the Attorney-at-Law Monopoly, it is stated that it aims to "ensure that everyone is entitled to professional legal assistance through the abolition of the lawyer's monopoly to provide such assistance" ${ }^{11}$. There is no specific justification for the need to pass such a law (despite the fact that in 2016 the Parliament introduced the Constitution completely opposite in content to the

${ }^{11}$ Poiasniuvalna zapyska do proektu Zakonu Ukrainy "Pro vnesennia zmin do Konstytutsii Ukrainy (shchodo skasuvannia advokatskoi monopolii)". URL: http://w1.c1.rada.gov.ua/pls/ zweb2/webproc4_1?pf3511=66242 (in Ukrainian). 
amendment). Therefore, the question of the expediency of such a step remained obscure to the public, which led to a mixed perception of the constitutional amendment.

Even more complicated is the situation with the draft law on advisory and other subsidiary bodies of the Verkhovna Rada of Ukraine, which was previously approved by the Verkhovna Rada on January 14, 2020. The explanatory note states that "the purpose of the proposed amendment is to legislate in the Constitution of Ukraine an effective mechanism for the organization and activity of the Verkhovna Rada of Ukraine" ${ }^{\text {12 }}$. However, the current wording of the Constitution, without being amended, allows the creation of such bodies, some of which have already been established and function successfully.

Finding out the purpose of submitting this bill has also become a challenge for the Constitutional Court of Ukraine, which exercises preliminary constitutional control over amendments to the Constitution. In the dissenting opinion of Judge Pervomaisky O.O. it was stated that "the participants in the constitutional proceedings actually expressed their own assumptions about the purpose of the Bill" and that "the judges of the Constitutional Court were in fact limited in their ability to clarify such important circumstances of the case as the reasons and motives for presenting the bill, its true purpose ..."13.

It is obvious that the lack of a clear formulation of the purpose of the constitutional reform casts doubt on its legitimacy, necessity, expediency, which adversely affects not only its implementation but also the authority of the Constitution as a whole.

\subsection{Content of the constitutional reform}

On the basis of a clear formulation of the purpose of constitutional reform, one can proceed to formulate its content. In fact, the content of constitutional reform is the constitutional changes which aim to achieve the goal of reform. It is natural that the content of the reform should provide the most optimal and least resource-intensive way of achieving the goal and, ultimately, ensure the effectiveness of the reform.

${ }^{12}$ Poiasniuvalna zapyska do proektu Zakonu Ukrainy "Pro vnesennia zminy do statti 85 Konstytutsii Ukrainy (shchodo konsultatyvnykh, doradchykh ta inshykh dopomizhnykh orhaniv Verkhovnoi Rady Ukrainy)". URL: https://w1.c1.rada.gov.ua/pls/zweb2/webproc4_1?pf3511= 66263 (in Ukrainian).

13 Okrema dumka suddi Konstytutsiinoho Sudu Ukrainy Pervomaiskoho O.O. stosovno Vysnovku Konstytutsiinoho Sudu Ukrainy u spravi za konstytutsiinym zvernenniam Verkhovnoi Rady Ukrainy pro nadannia vysnovku shchodo vidpovidnosti zakonoproektu pro vnesennia zminy do statti 85 Konstytutsii Ukrainy (shchodo konsultatyvnykh, doradchykh ta inshykh dopomizhnykh orhaniv Verkhovnoi Rady Ukrainy) (reiestr. № 1028) vymoham statei 157 i 158 Konstytutsii Ukrainy. URL: https://zakon.rada.gov.ua/laws/show/nb03d710-19\#n2 (in Ukrainian). 
The two important aspects of the content of reform - its constitutionality and systemic nature - should be stressed. The first is related to the existence of a number of formal and substantive requirements for constitutional amendments. Modern constitutions often contain a list of prohibitions on amending them. For example, the German Basic Law forbids any constitutional amendments concerning human dignity, the division of the Federation into Lands or their involvement in the legislative process (Part 3 of Art. 79) ${ }^{14}$. The Constitutions of Italy ${ }^{15}$ (Article 139) and France ${ }^{16}$ (Part 5 of Article 89) prohibit the revision of the constitutional provisions on the republican form of government. The Constitution of Ukraine forbids amendments if they envisage the abolition or restriction of the rights and freedoms of the individual and the citizen, or if they aimed at liquidation of independence or violation of the territorial integrity of Ukraine (Article 157, Part 1$)^{17}$.

These are formal bans on constitutional changes. However, the essential requirements arising from the principles of constitutional democracy are equally important. They concern the prohibition of the abolition of human rights, voidance of their guarantees, infringement of democracy, separation of powers, independence of the judiciary or other constitutional values. Of course, the mechanism for enforcing such bans is somewhat more complicated, since in countries with an insufficiently high level of constitutional culture, where traditions of constitutionalism are not deeply rooted, a formal approach to existing bans is usually applied. In our view, in those countries where the constitutional courts are vested with the function of preliminary control over constitutional amendments, their main task is to ensure compliance with the substantive prohibitions.

The systematic nature of the content of the reform is equally important. The systematic approach ${ }^{18}$ to constitutional reform primarily refers to the development of the content of the reform considered as a set of interrelated measures aimed at achieving its goal. An example of ignoring the systematic approach to constitutional reform is the aforementioned drafts on

${ }^{14}$ Basic Law for the Federal Republic of Germany, 23 May 1949 Last amended on 28 March 2019. URL: https://www.btg-bestellservice.de/pdf/80201000.pdf

${ }^{15}$ Constitution of the Italian Republic, 27 December 1947. URL: https://www.wipo.int/ edocs/lexdocs/laws/en/it/it037en.pdf

16 France's Constitution of 1958 with Amendments through 2008. URL: https://www.constituteproject.org/constitution/France_2008.pdf?lang=en

${ }^{17}$ Konstytutsiia Ukrainy, 28 chervnia 1996 roku zi zminamy stanom na veresen 2019 roku. URL: https://zakon.rada.gov.ua/laws/show/254\%D0\%BA/96-\%D0\%B2\%D1\%80/print (in Ukrainian).

18 Yolon P. Systemnyi pidkhid. Filosofskyi entsyklopedychnyi slovnyk. Kyiv, Abrykos, 2002. S. 584. URL: http://shron1.chtyvo.org.ua/Shynkaruk_Volodymyr/Filosofskyi_ entsyklopedychnyi_slovnyk.pdf (in Ukrainian). 
constitutional amendments of the President of Ukraine, which were submitted to the Ukrainian Parliament on August 29, 2019. These are seven bills, some of which provide for interconnected constitutional changes, in particular concerning the mechanism of separation of powers and other elements of the constitutional system (such as the people's legislative veto, the powers of the President of Ukraine and the Verkhovna Rada of Ukraine, reduction of the number of parliament members, extension of the list of grounds for early termination powers of deputies, etc.).

If adopted, they can have a significant impact on the constitutional system of Ukraine. At the same time, the logic and motives of the subject of submitting drafts on amendments to the Constitution of Ukraine, unfortunately, have not been publicly announced, and therefore it is unclear what the purpose is to pursue such a "fragmented" way of carrying out constitutional reform when the proposed constitutional changes are registered in one day in the form of several separate bills.

Moreover, there is no single concept of the constitutional reforms, indicating a lack of a systemic vision. What is only evident is that such a nonsystemic approach does not contribute to either the effectiveness of constitutional reform or its legitimacy.

\subsection{Strategy of the constitutional reform}

The next element of constitutional reform - its strategy is equally important. With a clearly defined objective of constitutional reform, one can begin to develop its strategy. The latter should be based on the requirements for the content of the reform (constitutionality, systematic nature) and provide for the most optimal ways of achieving its goal.

The constitutional reform strategy includes the concept of reform and a well-thought-out plan of measures necessary for both making constitutional changes according to the established procedure (discussed below) and putting it into practice.

In addition to its direct purpose - to ensure the effective implementation of the reform - the constitutional reform strategy also has a specific task - to ensure that the reform and all its stages are accepted by society. For this purpose, modern methods of deliberation are used: consultations, broad discussions, involvement in decision-making of different parts of the society. This process is based on the principles of inclusivity (involvement), accountability and transparency ${ }^{19}$.

19 Aitamurto Tanja, Landemore Hélène. Five design principles for crowdsourced policymaking: Assessing the case of crowdsourced off-road traffic law in Finland. Journal of Social Media for Organizations, 2015. Vol. 2, Issue 1. P. 1-19. 
Such involvement of citizens in the reform discussion process, on the one hand, enhances citizens' competence by giving them advisory functions, while emphasizing the complexity of democratic decision-making and, on the other hand, does not counterbalance the role of experts and professional managers ${ }^{20}$.

\subsection{Procedure and legitimacy of the constitutional reform}

An important element of constitutional reform is the legitimate order of its implementation. We mean the adoption or amendment of the Constitution in accordance with established legal procedures that comply with the principles of the constituent power. The legitimacy of the constitution implies its recognition by the society (consensus omnium) as the Fundamental Law, supreme, with respect to other legal acts. Such recognition is possible if the constitution conforms to the will of the people, which forms the basis of its constituent power, and contains a system of guarantees of freedom and human rights (substantive aspect of legitimacy).

Formulated by Emmanuel Joseph Sieyès in the 18th century, the concept of constituent power remains relevant today and retains considerable theoretical and practical potential. According to it, the highest manifestation of sovereignty is the constituent power that belongs to the people and is primary to all other powers (legislative, executive and judicial) ${ }^{21}$. It is achieved through the establishment of a constitutional order by the people by adopting a constitution, which is an example of the constitutional power of the people exercising. Therefore, the guarantee of the implementation of this will into the text of the Constitution is compliance with the procedure of adopting or amending the Constitution (procedural component of legitimacy). Any way of adopting a constituent constitution - a special representative institution, a parliament, or combining them with a referendum - has the purpose of exercising the constituent power of the people, and in substance is the mechanism of exercising such power.

In our opinion, constitutional changes are legitimate only if: 1) they are made by a proper subject (possessing constituent power or to which such power is delegated); 2) their content complies with law (not written acts, but law as a whole, primarily natural law and its principles); 3) are made in strict

20 Kolodii Antonina. Protses deliberatsii yak skladova demokratychnoho vriaduvannia. Demokratychni standarty vriaduvannia y publichnoho administruvannia. Materialy naukovopraktychnoi konferentsii. LRIDU NADU pry Prezydentovi Ukrainy, 4 kvitnia 2008 r. Lviv, 2008. S. 106-110 (in Ukrainian).

${ }^{21}$ Sieyès, What Is the Third Estate? The Old Regime and the French Revolution. University of Chicago Readings in Western Civilization, edited by Keith Michael Baker, John W. Boyer, Julius Kirsher, General Editors. Chicago and London: The University of Chicago Press, 1987. P. 154-179. 
compliance with the procedure established by the constitution. Only compliance with all three of these conditions results in the legitimacy of the amended constitution as a whole. Failure to comply with at least one of them casts doubt on its legitimacy.

\subsection{Mechanism of constitutional reform}

The effectiveness of constitutional reform is largely ensured by the mechanism of its implementation, based on the strategy of constitutional reform and includes the totality of measures envisaged by it.

As a rule, amendment to the constitution is not a sufficient measure of the implementation of the reform. This requires appropriate continuation in the laws, as well as the practical activity of public officials. Therefore, the constitutional reform mechanism is a final and important element of constitutional reform, which will ultimately define the implementation of the reform strategy and the achievement of its goal.

Together, all the described elements and features of constitutional reform are intended to ensure the development of the state as constitutional, improving its institutions on the basis of fundamental principles of constitutionalism.

\section{CONCLUSIONS}

To sum up, constitutional reform is a complex political and legal process that reflects both the level and the direction of development of society and the state. The development of a constitutional state puts forward a number of substantive and procedural requirements to constitutional reform, the observance of which ensures its constitutionality and effectiveness.

Under the constitutionality of constitutional reform, we understand its conformity not only and not so much with the "letter of the constitution" as with the spirit of constitutional principles, the universal ideas of constitutionalism.

Constitutional reform is characterized by a number of features that distinguish it from other related political and legal phenomena, including constitutional changes. Under the conditions of a constitutional state, they include: 1) the legitimate aim of the constitutional reform - focus on achieving a legitimate result (improvement of the system of separation of powers, organization of the state, guarantees of human rights, etc.); 2) the consequences for the constitutional system are tangible, serious, not precise; 3) legitimacy of the reform - adherence to the constitutional procedure for its conduction; 4) systemic nature (systematic reform). An optional feature is the effectiveness of constitutional reform, which is assessed in each case by the ratio of the defined goal and the achieved result. 
The basis for effective constitutional reform encompasses several mandatory structural elements: 1) the purpose of the reform; 2) its strategy; 3) the reform procedure that ensures its legitimacy; 4) tools (mechanism) for the constitutional reform. Each of the above elements has indispensable features that, under the conditions of a constitutional state, ensure "constitutionality" (ie, conformity with the ideas of constitutionalism) and the effectiveness of constitutional reforms.

\section{SUMMARY}

Constitutional reforms and constitutional amendments are a widespread phenomenon nowadays. Politicians in different countries throughout the world often call some political and / or legal events as constitutional reforms; typical in this context are examples of post-socialist Eastern European countries. But here are two questions. First, are all of these events truly constitutional reforms? To answer it, we will identify the features that characterize the phenomenon of constitutional reform. And second, are all constitutional reforms "constitutional" in their content and implementation? Under "constitutional" we mean conformity to the ideas of constitutionalism and the desire for the development of a constitutional state. The answer to this question requires highlighting the structural elements of constitutional reform and such their requirements that ensure the constitutionality of constitutional reform, as well as its effectiveness in the conditions of the constitutional state.

\section{REFERENCES}

1. European Parliament resolution of 13 April 2016 on the situation in Poland. URL: http://www.europarl.europa.eu/oeil/popups/ficheprocedure.do? lang=en\&reference $=2015 / 3031$ (RSP)

2. European Parliament resolution of 14 September 2016 on the recent developments in Poland and their impact on fundamental rights as laid down in the Charter of Fundamental Rights of the European Union. URL: http://www.europarl.europa.eu/sides/getDoc.do?type=TA\&reference=P8-TA2016-0344\&language $=\mathrm{EN}$

3. European Parliament resolution of 15 November 2017 on the situation of the rule of law and democracy in Poland. URL: http://www.europarl.europa.eu/ sides $/$ getDoc.do?type=TA\&language=EN\&reference=P8-TA-2017-0442

4. European Parliament resolution of 28 January 2020 on the Functioning of democratic institutions in Poland. URL: http://assembly.coe.int/ nw/xml/XRef/Xref-DocDetails-EN.asp?FileID=28504\&lang=EN

5. Basic Law for the Federal Republic of Germany, 23 May 1949 Last amended on 28 March 2019. URL: https://www.btg-bestellservice.de/pdf/ 80201000.pdf 
6. Constitution of the Italian Republic, 27 December 1947. URL: https://www.wipo.int/edocs/lexdocs/laws/en/it/it037en.pdf

7. Venice Commission Opinion on three legal questions arising in the process of drafting the new Constitution of Hungary, Strasbourg, 28 March 2011, p. 8, URL: http://www.venice.coe.int/webforms/documents/ default.aspx ?pdffile $=$ CDL-AD $(2011) 001-\mathrm{e}$

8. Venice Commission Opinion on the New Constitution of Hungary, Strasbourg, 20 June 2011. URL: http://www.venice.coe.int/webforms/ documents/default.aspx?pdffile=CDL-AD(2011)016-e

9. Venice Commission Opinion on the amendments to the Constitution of Ukraine adopted on 8.12.2004 adopted by the Commission at its 63rd plenary session, Venice, 10-11 June 2005. URL: https://www.venice.coe.int/ webforms/documents/?pdf=CDL-AD(2005)015-e

10. Pro vnesennia zmin do Konstytutsii Ukrainy (shchodo pravosuddia). Zakon Ukrainy vid 02.06.2016 № 1401-VIII. URL: https://zakon.rada.gov.ua/ laws/show/1401-19 (in Ukrainian).

11. Pro vnesennia zmin do Konstytutsii Ukrainy (shchodo stratehichnoho kursu derzhavy na nabuttia povnopravnoho chlenstva Ukrainy $v$ Yevropeiskomu Soiuzi ta v Orhanizatsii Pivnichnoatlantychnoho dohovoru). Zakon Ukrainy vid 07.02.2019 № 2680-VIII. URL: https://zakon.rada.gov.ua/ laws/show/2680-19 (in Ukrainian).

12. Pro vnesennia zmin do Konstytutsii Ukrainy shchodo provedennia cherhovykh vyboriv narodnykh deputativ Ukrainy, Prezydenta Ukrainy, deputativ Verkhovnoi Rady Avtonomnoi Respubliky Krym, mistsevykh rad ta silskykh, selyshchnykh, miskykh holiv. Zakon Ukrainy vid 01.02.2011 № 2952-VI. URL: https://zakon.rada.gov.ua/laws/show/2952-17 (in Ukrainian).

13. Poiasniuvalna zapyska do proektu Zakonu Ukrainy "Pro vnesennia zmin do Konstytutsii Ukrainy (shchodo skasuvannia advokatskoi monopolii)". URL: http://w1.c1.rada.gov.ua/pls/zweb2/webproc4_1?pf3511=66242 (in Ukrainian).

14. Poiasniuvalna zapyska do proektu Zakonu Ukrainy "Pro vnesennia zminy do statti 85 Konstytutsii Ukrainy (shchodo konsultatyvnykh, doradchykh ta inshykh dopomizhnykh orhaniv Verkhovnoi Rady Ukrainy)". URL: https://w1.c1.rada.gov.ua/pls/zweb2/webproc4_1?pf3511=66263 (in Ukrainian).

15. Okrema dumka suddi Konstytutsiinoho Sudu Ukrainy Pervomaiskoho O.O. stosovno Vysnovku Konstytutsiinoho Sudu Ukrainy u spravi za konstytutsiinym zvernenniam Verkhovnoi Rady Ukrainy pro nadannia vysnovku shchodo vidpovidnosti zakonoproektu pro vnesennia zminy do statti 85 Konstytutsii Ukrainy (shchodo konsultatyvnykh, doradchykh ta 
inshykh dopomizhnykh orhaniv Verkhovnoi Rady Ukrainy) (reiestr. № 1028) vymoham statei 157 i 158 Konstytutsii Ukrainy. URL: https://zakon.rada.gov.ua/laws/show/nb03d710-19\#n2 (in Ukrainian).

16. Konstytutsiia Ukrainy, 28 chervnia 1996 roku zi zminamy stanom na veresen 2019 roku. URL: https://zakon.rada.gov.ua/laws/show/254\% D0\%BA/96-\%D0\%B2\%D1\%80/print (in Ukrainian).

17. Ahafonova N.V. Konstytutsiina reforma $\mathrm{v}$ Ukraini: poniattia, instytutsiinyi mekhanizm ta zabezpechennia efektyvnosti. (Constitutional Reform in Ukraine: Concept, Institutional Mechanism and Effectiveness Support). Avtoreferat dysertatsii na zdobuttia naukovoho stupenia doktora yurydychnykh nauk. Kyiv, 2017 (in Ukrainian).

18. Aitamurto Tanja, Landemore Hélène. Five design principles for crowdsourced policymaking: Assessing the case of crowdsourced off-road traffic law in Finland. Journal of Social Media for Organizations, 2015. Vol. 2, Issue 1. P. 1-19.

19. Kolodii Antonina. Protses deliberatsii yak skladova demokratychnoho vriaduvannia. Demokratychni standarty vriaduvannia y publichnoho administruvannia. Materialy naukovo-praktychnoi konferentsii. LRIDU NADU pry Prezydentovi Ukrainy, 4 kvitnia 2008 r. Lviv, 2008. S. 106-110 (in Ukrainian).

20. Sieyès, What Is the Third Estate? The Old Regime and the French Revolution. University of Chicago Readings in Western Civilization, edited by Keith Michael Baker, John W. Boyer, Julius Kirsher, General Editors. Chicago and London: The University of Chicago Press, 1987. P. 154-179.

21. Sundquist James. L. Constitutional reform and effective government. Washington D.C.: Brookings Institution, Revised edition, 1992.

22. Yolon P. Systemnyi pidkhid. Filosofskyi entsyklopedychnyi slovnyk. Kyiv, Abrykos, 2002. S. 584. URL: http://shron1.chtyvo.org.ua/Shynkaruk_ Volodymyr/Filosofskyi_entsyklopedychnyi_slovnyk.pdf(in Ukrainian).

\section{Information about the author:} Olena Boryslavska,

Doctor of Juridical Sciences, Docent, Professor at the Constitutional Law Department, Ivan Franko National University of Lviv ORCID: https://orcid.org/0000-0001-8338-0966 Researcher ID: https://publons.com/researcher/H-2177-2019/ 